\title{
A study on effect of world trade organization on Iran's membership on export of Iranian handmade carpet
}

\author{
Mansoureh Golmeymi $^{a^{*}}$ and Mehrdad Syadat Nasab ${ }^{b}$
}

${ }^{a}$ Ferdows Institute of Higher Education, Mashhad, Iran; Armenian State Agrarian University, Yerevan, Armenia

${ }^{b}$ Yasuj Branch, Islamic Azad University, Yasuj, Iran

\section{H R O N I C L E}

Article history:

Received May 16, 2013

Received in revised format

18 August 2013

Accepted 18 August 2013

Available online

August 282013

Keywords:

Iranian handmade carpet

Quality of work life

Team work

\section{A B S T R A C T}

\begin{abstract}
World Trade Organization (WTO) has been established to facilitate fringe trade in the world and there are many studies associated with the effect of WTO membership on export of various countries. This paper presents an empirical investigation to find the effect of WTO membership on export of Iranian handmade carpet. The survey uses insights from 80 experts who have at least ten years of related job experiences in carpet industry by performing an expletory and using descriptive and quantitative method for analyzing the data. The results of the survey indicate that Iran's membership in WTO will most likely reduce the sales price of handmade carpet. In addition, Iran's membership in WTO will increase scientific and professional power in handmade carpet. It will also help industry get more exposure into international market.
\end{abstract}

(C) 2013 Growing Science Ltd. All rights reserved.

\section{Introduction}

World trade organization is the only global international organization designed to establish and help implement rules of trade between nations. Since 1995, the WTO's goal has been considered to reduce or eliminate trade barriers and restrictions word wide to help producers of goods and services, exporters, and importers conduct their business by reducing costs (Ma \& Wang, 2001). During the past few years, there have been various studies on learning the effects of WTO membership. Thanh and Duong (2009) provided a comprehensive review of the socio-economic changes in Vietnam since its WTO accession in early 2007. They reported that previous studies significantly underestimated the effects of WTO accession and integration on Vietnam's economy, whilst failing to rigorously analyze foreign capital inflows and related macroeconomic affairs. However, during the years of 2007-2008, there was a remarkable improvements in Vietnam's economic performance, from real perspectives to *Corresponding author

E-mail address: golmeymi@gmail.com (M. Golmeymi) 
social issues and economic institutions. Nevertheless, quality of growth remained modest, trade deficit widened, inflation surged, while Vietnam's vulnerability to negative external shocks gets increasingly apparent.

Golmeymi et al. (2013) investigated the impacts of Iran's membership in WTO to empower this industry by performing an empirical survey among 100 experts in this industry. Their findings indicated that access to WTO plays an essential role on increasing production of handmade carpet and developing this industry. They also explained that the industry needed to incorporate the recent advances on technology to ensure cost efficient production materials.

Azad et al. (2012) presented an empirical study to learn more about challenges in carpet industry using factor analysis. The proposed study of this paper designed a questionnaire in Likert scale and distributed it among experts in Carpet industry. They analyzed the data using factor analysis and categorized eight factors including specialized relationships, knowledge coordinator, knowledge tool, knowledge organization, knowledge processes, knowledge chain, knowledge hardware and Knowledge feasibility study. Rangriz et al. (2012) implemented various mathematical techniques to consider various actions for changing threats to opportunities, reducing unnecessary costs, increasing revenue and market share, etc. The proposed model of this paper implemented Fuzzy analytical hierarchy process (AHP), Benefits-Opportunities-Costs-Risks (BOCR) method to find possible benefit, risk and cost components.

\section{Material and Methods}

The current study can be considered as an explanatory one mainly; however to support hypotheses as well as developing a conceptual framework, it can be an exploratory research. The theoretical part of this study is based on secondary data obtained from library study while the empirical part is based on gathered primary data from statistical population, which are exporters of handmade carpets in Iran as well as managers in Ministry of Commerce and National Center Carpet management who have more 10 year experience in this industry. The instrument of this research is a questionnaire consists of 31 closed-ended questions developed based on research hypotheses. Furthermore, for data collecting simple random sampling without replacement was chosen. All collected primary data will be analyzed based on different statistical methods with the aid of SPSS program.

\section{Result and Discussion}

There is not error in model of random. There searcher has been got list (100 individuals) and then 80 samples have been selected as sample size based on table generated by Krejcie and Morgan (Krejcie, R. V., \& Morgan, D. W,1970) as follows,

$$
n=\frac{N \cdot t^{2} \cdot p(1-p)}{N \cdot d^{2}+t^{2} \cdot p(1-p)}
$$

where $n$ is the sample size, $N$ is the total statistical society, $t^{2}$ is the t-student value, $d^{2}$ is the approximation of the estimated society parameter and $P$ is the probability of existing the adjective. In our survey, $N=100$, the level of significance is five percent $(\alpha=0.05)$ and $P=0.5$. Therefore, we have,

$$
n=\frac{100 \times 1.96^{2} \times 0.5(1-0.5)}{100 \times 0.05^{2}+1.96^{2} \times 0.5(1-0.5)}=80 .
$$

Reliability or trusting the measuring instrument consists of the measuring instrument made for measuring a variable or characteristic, which is resulted in the same productions if it is used in the other places or times in the same conditions. In other words, an instrument is reliable or valid if it can 
be generalized and resulted in the same productions in the same conditions. Table 1 demonstrates Cronbach alpha for the questionnaire of this survey,

Table 1

Cronbakh's Alpha Coefficients of Research Instrument

\begin{tabular}{clc}
\hline Row & Headline of questions & Alpha \\
\hline 1 & Decrease of the sales price of handmade carpet & 0.7219 \\
2 & Increase of scientific and professional power in the field of production & 0.9301 \\
3 & Investigation about market need and taste in international market & 0.7776 \\
\hline
\end{tabular}

As Table 1 shows, all Cronbach alphas have been well above the minimum desirable level of 0.7.

There are some main factors, which would be accomplished when Iran joins to WTO, including decrease in price of handmade carpet, increase in scientific business methods, better understanding market needs, disabling competitor's tricks, making comparative advantage and having more control in Iran's carpet market. The first step to evaluate the data gathered from our survey is to understand whether the data are normally distributed or not. This could be verified using Kolmogorov-Smirnov test. Table 2 shows details of our findings.

\section{Table 2}

The results of Kolmogorov-Smirnov Test

\begin{tabular}{llllll}
\hline Variables & Mean & Standard & Kolmogorov-Smirnov & Sig. & Result \\
\hline Decrease of the sales price of & 3.33 & 0.740 & 1.45 & 0.03 & Abnormal \\
Increase of scientific \& & 4.07 & 0.941 & 1.462 & 0.02 & Abnormal \\
Investigation about market need & 4.33 & 0.671 & 1.502 & 0.02 & Abnormal \\
\hline
\end{tabular}

The null hypothesis of this survey is that the data are not normally distributed and since the level of significance is five percent we can conclude that none of the variables is normally distributed.

\subsection{The first hypothesis: The relationship between WTO membership and selling price}

The first hypothesis of this survey investigates whether Iran's membership in WTO influences on Iranian handmade carpet price reduction. The following table indicates frequency distribution of the first hypothesis.

Table 3

Frequency distribution of the first hypothesis

\begin{tabular}{|c|c|c|c|c|c|c|c|c|}
\hline \multirow{2}{*}{\multicolumn{2}{|c|}{ Question No }} & \multicolumn{5}{|c|}{ Items } & \multirow[b]{2}{*}{ Mean } & \multirow{2}{*}{$\begin{array}{l}\text { Standard } \\
\text { Division }\end{array}$} \\
\hline & & Very & Little & Average & Much & Very & & \\
\hline \multirow{2}{*}{10} & Frequency & 9 & 10 & 24 & 29 & 8 & \multirow{2}{*}{3.21} & \multirow{2}{*}{1.143} \\
\hline & Percentage & 11.3 & 12.5 & 30 & 36.2 & 10 & & \\
\hline \multirow{2}{*}{11} & Frequency & 7 & 5 & 22 & 36 & 10 & \multirow{2}{*}{3.46} & \multirow{2}{*}{1.078} \\
\hline & Percentage & 8.7 & 6.3 & 27.5 & 45 & 12.5 & & \\
\hline \multirow{2}{*}{12} & Frequency & 6 & 9 & 18 & 33 & 14 & \multirow{2}{*}{3.50} & \multirow{2}{*}{1.136} \\
\hline & Percentage & 7.5 & 11.3 & 22.5 & 41.2 & 17.5 & & \\
\hline \multirow{2}{*}{13} & Frequency & 12 & 10 & 15 & 30 & 13 & \multirow{2}{*}{3.27} & \multirow{2}{*}{1.302} \\
\hline & Percentage & 15 & 12.5 & 18.7 & 37.5 & 16.3 & & \\
\hline \multirow{2}{*}{14} & Frequency & 9 & 10 & 30 & 23 & 8 & \multirow{2}{*}{3.13} & \multirow{2}{*}{1.122} \\
\hline & Percentage & 11.3 & 12.5 & 37.5 & 28.7 & 10 & & \\
\hline \multirow{2}{*}{15} & Frequency & 6 & 9 & 21 & 35 & 9 & \multirow{2}{*}{3.40} & \multirow{2}{*}{1.074} \\
\hline & Percentage & 7.5 & 11.3 & 26.2 & 43.7 & 11.3 & & \\
\hline
\end{tabular}

To examine the first hypothesis since the data is not normally distributed we use one-sample sign test where $\left(\mathrm{H}_{0}: \mu \leq 3\right)$ and $\left(\mathrm{H}_{1}: \mu>3\right)$. In other words, the null hypothesis states that Iran's membership in WTO does not influence on reducing sales price of handmade carpet and the level of significance is five percent. Table 4 shows details of our findings, 
Table 4

One-sample Sign Test of Hypothesis 1

\begin{tabular}{ccccc}
\hline Statistical mean & Number less than & Number equal & Number more & Significance \\
\hline 3.33 & 15 & 5 & 60 & 0.03 \\
\hline
\end{tabular}

According to the results of Table 4, significance level is 0.03 , which is less than 0.05 , so $\mathrm{H}_{0}$ is rejected and $\mathrm{H}_{1}$ accept. It means Iran's membership in WTO can influence on handmade carpet price reduction. Note that there is a difference between the current situation and the desirable situation. In today's competitive market, price has become an important factor and the effect of price reduction may increase demand for this product.

\subsection{The second hypothesis: The effect of WTO membership on increase in professional power}

The second hypothesis is associated with the effect of Iran's WTO membership in increasing scientific and professional power in handmade carpet producing. Table 5 demonstrates the summary of our survey,

Table 5

Frequency distribution for the second hypothesis

\begin{tabular}{|c|c|c|c|c|c|c|c|c|}
\hline & \multirow{2}{*}{ Question No } & \multicolumn{5}{|c|}{ Items } & \multirow[b]{2}{*}{ Mean } & \multirow[b]{2}{*}{ Standard } \\
\hline & & Very & Little & Average & Much & Very & & \\
\hline \multirow{2}{*}{16} & frequency & 4 & 7 & 8 & 29 & 32 & \multirow{2}{*}{3.97} & \multirow{2}{*}{1.147} \\
\hline & Percentage & 5 & 8.8 & 10 & 36.2 & 40 & & \\
\hline \multirow{2}{*}{17} & frequency & 3 & 4 & 15 & 25 & 33 & \multirow{2}{*}{4.01} & \multirow{2}{*}{1.073} \\
\hline & Percentage & 3.8 & 5 & 18.8 & 31.2 & 41.2 & & \\
\hline \multirow{2}{*}{18} & frequency & 3 & 1 & 12 & 27 & 37 & \multirow{2}{*}{4.17} & \multirow{2}{*}{0.990} \\
\hline & Percentage & 3.8 & 1.3 & 15 & 33.8 & 46.3 & & \\
\hline \multirow{2}{*}{19} & frequency & 3 & 5 & 11 & 28 & 33 & \multirow{2}{*}{4.03} & \multirow{2}{*}{1.072} \\
\hline & Percentage & 3.8 & 6.2 & 13.8 & 35 & 41.2 & & \\
\hline \multirow{2}{*}{20} & frequency & 3 & 4 & 6 & 29 & 38 & \multirow{2}{*}{4.18} & \multirow{2}{*}{1.032} \\
\hline & Percentage & 3.8 & 5 & 7.5 & 36.2 & 47.5 & & \\
\hline
\end{tabular}

Like the first hypothesis, we used $\mathrm{H}_{0}$ and $\mathrm{H}_{1}$ test regarding to the amount of " $\mu$ ", so there should be tested the following assumptions:

$\left\{H_{0}: \quad \mu \leq 3\right.$ : Iran's membership in WTO will not increase scientific and professional power in handmade carpet production.

$\left\{H_{1}: \quad \mu>3\right.$ : Iran's membership in WTO will increase scientific and professional power in handmade carpet production.

Table 6

One-sample Sign Test of Hypothesis 2

\begin{tabular}{ccccc}
\hline Statistical & Number less than & Number equal with & Number more & Significance \\
\hline 4.2 & 7 & 5 & 68 & 0.028 \\
\hline
\end{tabular}

As we consider from the result of Table 6, significance is equal 0.028, which is less than $\alpha=0.05$. Therefore, $\mathrm{H}_{0}$ is rejected and $\mathrm{H}_{1}$ is accepted. This means Iran's membership in WTO can increase the scientific and professional power in the field of production of handmade carpet.

\subsection{The third hypothesis: WTO membership and market exposure}

The third hypothesis of this survey is associated with the relationship between WTO membership and market exposure. Table 7 demonstrates the summary of some statistics associated with the third hypothesis of this survey. 
Table 7

Frequency Distribution of the third hypothesis

\begin{tabular}{|c|c|c|c|c|c|c|c|c|}
\hline \multirow{2}{*}{\multicolumn{2}{|c|}{ Question No }} & \multicolumn{5}{|c|}{ Items } & \multirow[b]{2}{*}{ Mean } & \multirow{2}{*}{$\begin{array}{l}\text { Standard } \\
\text { Division }\end{array}$} \\
\hline & & $\begin{array}{l}\text { Very } \\
\text { Little }\end{array}$ & Little & Average & Much & $\begin{array}{l}\text { Very } \\
\text { Much }\end{array}$ & & \\
\hline \multirow{2}{*}{21} & frequency & 2 & 0 & 12 & 29 & 37 & \multirow{2}{*}{4.23} & \multirow{2}{*}{0.889} \\
\hline & Percentage & 2.5 & 0 & 15 & 36.3 & 46.2 & & \\
\hline \multirow{2}{*}{22} & frequency & 0 & 0 & 2 & 23 & 55 & \multirow{2}{*}{4.66} & \multirow{2}{*}{0.526} \\
\hline & Percentage & 0 & 0 & 2.5 & 28.8 & 68.7 & & \\
\hline \multirow{2}{*}{23} & frequency & 3 & 1 & 8 & 26 & 42 & \multirow{2}{*}{4.28} & \multirow{2}{*}{0.970} \\
\hline & Percentage & 3.8 & 1.3 & 10 & 32.5 & 52.4 & & \\
\hline \multirow{2}{*}{24} & frequency & 3 & 3 & 7 & 32 & 35 & \multirow{2}{*}{4.16} & \multirow{2}{*}{0.999} \\
\hline & Percentage & 3.8 & 3.8 & 8.8 & 39.9 & 43.7 & & \\
\hline
\end{tabular}

Similar to the previous two hypotheses, the null hypothesis states that there was no relationship between WTO membership and market exposure and the level of significance is five percent. The results also confirm that WTO membership could increase the change of having better market exposure.

\subsection{Freedman test}

In this section, we present details of ranking three hypotheses in terms of their relative importance. To accomplish this task, we need to use Freedman test. Table 8 summarizes the results of our survey.

Table 8

The summary of Freedman test

\begin{tabular}{clc}
\hline Row & Index & Amount \\
\hline 1 & Friedman's k2 & 147.05 \\
2 & Degrees of freedom $(\mathrm{df})$ & 5 \\
3 & Significance level & 0.000 \\
\hline
\end{tabular}

As can be seen from the results of Table 8, significance level of the Friedman test is equivalent to 0.000 . Therefore, we can reject the null hypothesis $\left(\mathrm{H}_{0}\right)$ and accept $\mathrm{H}_{1}$. Table 9 shows details of our survey on ranking various factors.

Table 9

Rank of Priorities for Result of Iran's Membership in WTO

\begin{tabular}{lcc}
\hline Factors & Average ranks & Priority \\
\hline Decrease of the sales price of handmade carpet & 2.34 & 3 \\
Increase of scientific and professional power in the field of production & 4.22 & 2 \\
Investigation about market need and taste in international market & 4.94 & 1 \\
\hline
\end{tabular}

According to the statistical analysis as well as theoretical studies presented in this paper, a conceptual model is presented based on applying knowledge management and joining to WTO by the country in order to achieve advantages and benefits in the global handmade carpet markets.

According to this model, by lifting barriers to become a member of WTO as well as applying and developing knowledge management in producing handmade carpet and international marketing activities which is one way to join WTO, handmade carpet industry can achieve competitive advantage. This includes different benefits including reduction of sales cost, rising business knowledge, better understanding market needs, increasing comparative advantage and monitoring global market. Indeed, this model shows how handmade carpet industry of Iran can be benefited by joining to WTO, which would be achieved by lifting barriers and applying knowledge management in the handmade carpet industry. 


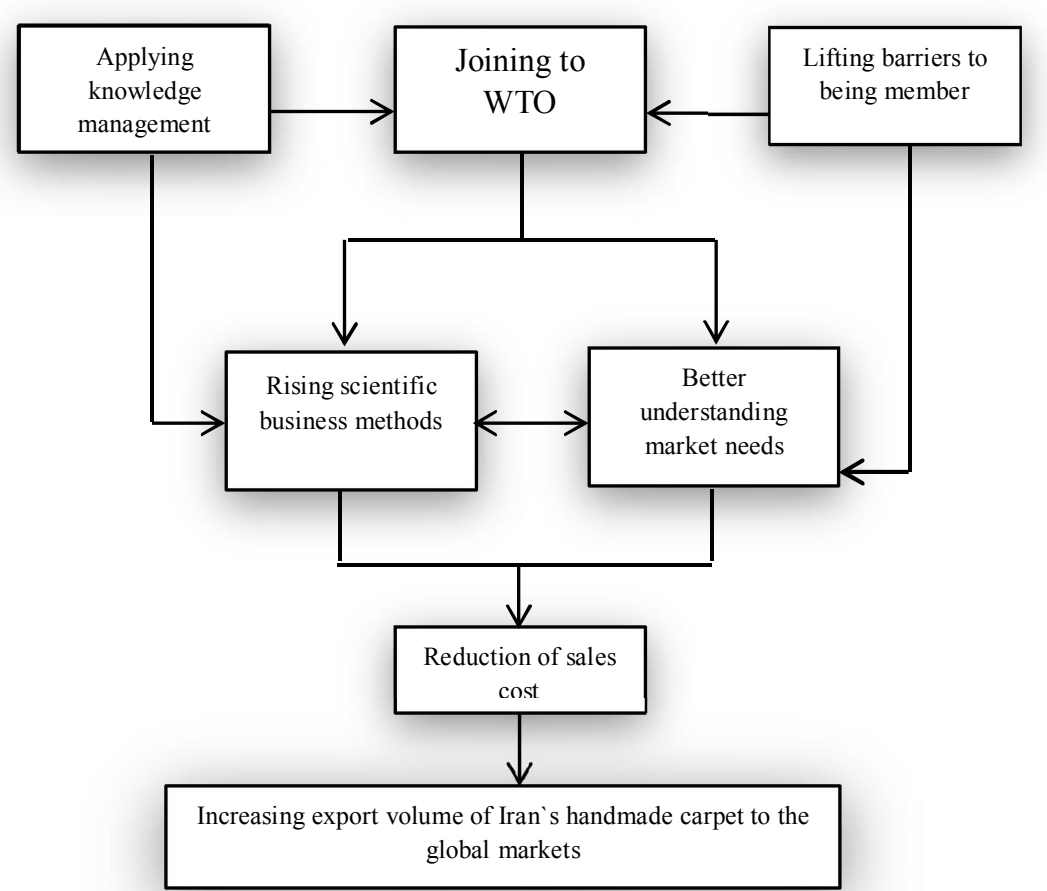

Fig. 1. The conceptual framework of Iran`s WTO membership

\section{Conclusion}

In this paper, we have presented an empirical investigation to examine the effects of WTO membership on empowering Iranian handmade carpet. The results of the survey have indicated that WTO membership will help having better market exposure, increase domestic market capabilities to become more familiar with new advances on information technology and it will reduce the price of hand made products. One immediate consequence of price reduction is an increase in market share, which may create a more attractive market.

\section{Acknowledgment}

This project has been supported by Iran's Carpet National Center.

\section{Reference}

Azad, N., Seyed Aliakbar, S.M., \& Ansar, M. (2012). Investigating knowledge management critical success factors in carpet industry. Management Science Letters, 2(8), 2717-2722.

Golmeymi, M., Mirvaisi, M., Maleki, B., \& Shirzour Aliabadi, Z. (2013). An empirical study on the effect of WTO membership on Iranian Handicraft industry: A case study of Persian carpet. Management Science Letters, 3(5), 1375-1380.

Krejcie, R. V., \& Morgan, D. W. (1970). Determining sample size for research activities. Educational and Psychological Measurement, 30, 607-610.

Ma, J., \& Wang, Z. (2001). Winners and losers of China's WTO entry. China Business Review, 28(2), $22-5$.

Rangriz, H., Hosseinpour, M., \& Esmaeili, S. (2012). A BOCR and Fuzzy AHP method for identification and prioritization of carpet industry strategies. Management Science Letters, 2(8), 2869-2874.

Thanh, V. T., \& Duong, N. A. (2009). Vietnam after two years of WTO accession: What lessons can be learnt?. ASEAN Economic Bulletin, 26(1), 115-135.

$\mathrm{Vu}, \mathrm{T} . \mathrm{A}$. (2008). Challenges to be overcome by Vietnam after one year of WTO member, Economic Development Review, 17, 19-21. 